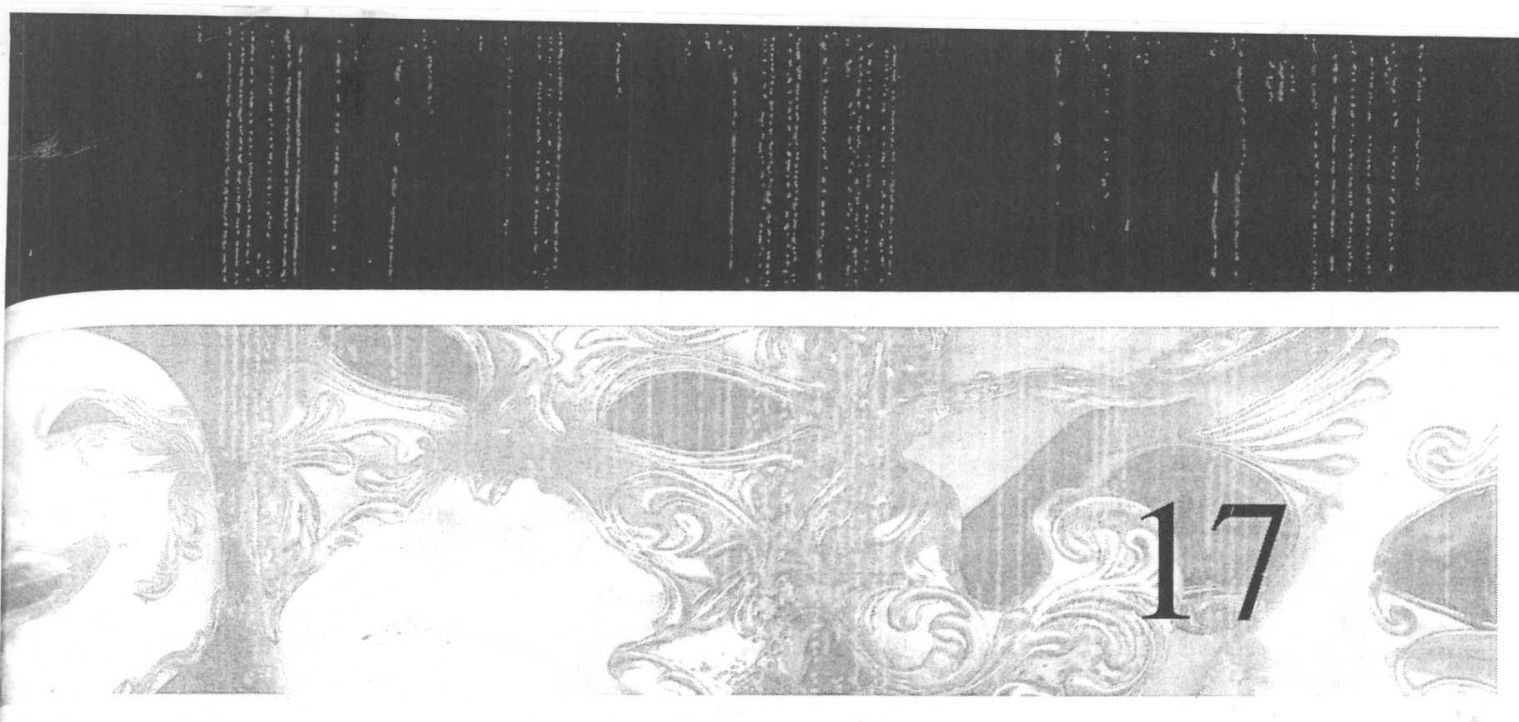

\title{
Class, Culture and Morality: Legacies and Logics in the Space for Identification
}

The conditions of possibility for class identity are always shaped by forms of capital, types of governance and claims for legitimacy. Identity always includes processes of identification and recognition (or dis-identification and mis-recognition), and identity is located within a symbolic system of value attribution; that is, some identities are considered worth having and others not. The concept identity also invokes assumptions about social compositions and how we value and 'count' people, individual or group identity, and assumptions about consciousness and property ownership of oneself: we 'have' an identity, it is something with which that we own in ourselves, or it is something we make an identification. These assumptions: recognition, value, social composition, counting and consciousness all have their routes in debates about the concept of class, which produce interesting configurations for identity and how it can be known. All these conceptualisations exist within capitalism, the system for extracting value and making profit from labour and commodities.
When we examine the historical production of the concept class what we see is how it has operated to conceptualise inequalities of different kinds, of which identity is only one aspect. For instance, it has been convincingly argued from a range of disciplines that the working class had to learn to recognise themselves as such. The concept working class was initially developed through terms of exclusion - that which was not middle class and the term middle class was made from the distance drawn from the aristocracy and the urban mass. The term class has always been loaded with moral-value, with long historical legacies (stretching back to the Ancient Greeks, as Ste Croix [1981] notes). As a term, like all other terms, it codifies histories and interests within its definition. This is not to say that it is purely discursive, for it is a term that has very powerful material effects. As Mary Poovey notes:

The reified abstractions that standardized modes of knowing generate then produce effects that are simultaneously symbolic and material- as we see, 
for example, in the case of the census, where abstractions like 'minorities' (however defined) receive differential symbolic and material treatment according to prevailing assumptions about their relative value to society as a whole. (Poovey 1995: 5)

Some theorists maintain that definitions of class are strictly restricted to the economic, but British Imperialism, for instance, was not just an economic system, it was legitimated through a moral project: 'the civilising mission'. Capital rarely cares who it extracts value from, but nation-states and forms of governance enable moral values to be attributed to different classes through the binary oppositions of good-bad citizen, respectable-unrespectable, deserving-undeserving. Class-ifications are never neutral terms, but emerge as the result of interests that can be consolidated in abstract explanations, not only shaped by interest groups in the conditions of their emergence, but also by their citation, their performative function, and the struggles for legitimation that take place across different sites of institutionalisation such as welfare, law, education and the media. Social theorists are part of this legitimation/institutionalisation process, and the current state of debates about class in social and cultural theory show the range of interests and perspectives at stake between those who want to use and organise around the category for purposes of social justice and those who want to deny the existence of class to hide and legitimate their own privilege. What is significant is the longevity of the term, the way it is used as means for explaining all social organisation, how it is almost impossible to extract it from the entwined condition of its utterance, how it is so intimately tied up to nation, sexuality, race and gender, how it has been known through proximity to labour, and how it is mostly disconnected from matters of identity.

For the purposes of this chapter I will begin with the historical legacies that inform the use of the concept class, examining what was at stake in the development of particular definitions, moving on to look at how class has a long and partially hidden history (although depending on who does the looking) in the idea of self, which has significance for how identity can be know, recognised and performed. I will then explore in detail, through reference to ethnographic research, how relationships to class are shaped by morality, culture and affect and lived by a group of white, working-class women; then extending the argument into other research to examine the relationship between value and identity.

\section{THE EMERGENCE OF THE CONCEPT 'CLASS': TRAJECTORIES AND LEGACIES}

There are two major theoretical/political trajectories to the development of class as a concept. The first, Marxist, prioritises the role of exploitation and struggle in the making of classes and hence social relations more generally; the second focuses on class hierarchies and status without reference to struggle and exploitation (Cannadine, 1988). For Marxists, class has a number of distinctive features: class is a relationship always relative to other groups; the relationship is antagonistic because it is based on exploitation and control. Therefore class is about the struggle between groups over control, in which exploiters and exploited fight it out. The antagonism is formed in the process of production; and class is abjective relationship. It does not matter what people think about their location (subjective class position, identity), rather, it is about the location of people according to economic relationships (Callinicos and Harman, 1987) or ideological positioning (Althusser, 1971). And just because somebody believes they are middle class does not mean that they stop being exploited by the capitalist class. For Marx, however, coming into consciousness about class exploitation, becoming aware of 
one's positioning, and challenging the standpoints of the ruling ideas of the ruling class, would lead to a collective recognition of a 'class for itself' (the proletariat) that could effectively oppose and overthrow the bourgeoisie. Coming into consciousness, which could be seen as recognising a class identity, entails an understanding of position, capitalism and ideology. More generally, for Marx and Engels consciousness was not an individual matter, rather a 'mode of life':

As individuals express their life, so they are. What they are, therefore, coincides with what they produce and how they produce. The nature of individuals thus depends on the material conditions which determine their production. (1968[1848]: 108)

Individuals identify as a class in so far as they have to battle against another class, making class identity into a temporal/spatial strategic matter formed through conflict, exploitation and unequal relations of power. For Marx it is the bourgeoisie that calls into existence the modern working-class - the proletarians - "who live only so long as they find work and who find work only so long as their labour increases capital' (Marx and Engels, 1968[1848]: 51). The proletariat is 'the special and essential product of the bourgeoisie'. It is only when workers form unions, or what he calls 'combinations' can the precarious nature of their existence be made more secure, but only temporarily. So, class is not an identity for Marx and Engels, instead a description of the conditions of existence of labour under capitalism, and consciousness is not about taking up an identity or making an identification with a category but of recognising the exploitative conditions of one's existence.

This perspective could not be more different to the other major trajectory that forms the etymology of the concept class. With no need for a revolution to overthrow the bourgeoisie, this perspective concerns itself with the precise nature of classification, employment 'aggregates', status and how to best conceptualise occupational groups in a hierarchical order. It began in 1665 with William Petty, who set out to calculate the value of the 'people' of England for taxation purposes. Petty is attributed with devising what is now known as the 'political arithmetic' tradition of class analysis (associated with the hierarchy rather than the class struggle tradition) in order to enumerate what was otherwise un-measurable (Poovey, 1995). The person was conceptualised as a quantifiable, knowable, hence governable object tightly linked to national concerns and formation. James Thompson documents how, throughout the eighteenth century, there was a 'drive toward an abstract and consistent and therefore predictable representation of exchange, that is, toward (new) scientific, quantitative, and mathematical modelling' (1996: 28). These processes involved the calculation and quantification of labour, making the person an object of calculation, subject to domination and impersonal forces beyond their control. These processes of calculation became institutionalised in the eighteenth century through the machinery of the New Poor Law, which generated an avalanche of new information and mandated more and more far-reaching, fact-gathering, inspection and legislation.

The continued emphasis on measurement and calculation deflects attention away from the reasons for inequality into a methodological debate about how best to measure, into scientific calculus, as if divisions were the result of mathematical formulae. The significant difference between the two main perspectives is cause and effect: one attempts to explain why classes come into effect, while the other measures the end product of historical social relations. But central to both is work: labour as a force that shapes all relations and the potential for subjectivity (selling one's labour) and work organised into occupations for measurement. Work also becomes central to working-class organisations such as trade unions as a source of potential identification. Hence also feminist critiques which showed, firstly via Marxism, that paid labour was only one way in which 
capitalism operates, pointing to the significance of domestic labour for social reproduction thus sustaining exploitation and secondly via feminist stratification critiques which argue that measuring women's social class on husband's and father's occupation was inadequate (Crompton, 1993; Stanworth, 1984).

Yet, as Mike Savage (2003) notes, classconsciousness was also central to traditions in British sociology and anthropology between 1950s-mid-1970s that focused on stratification. In the mid-1970s he identifies a shift to the structural aspects of inequality, within this non-Marxist tradition. For instance, John Goldthorpe (1996) identified with the move to structural measurement, after much debate within sociology and political science refined the British Government's traditional five Registrar General's categories of social class into seven new categorizations, all based on the collation of occupational groups: for example, professional/managerial to unskilled, to take into account economic changes, such as the decline of the manufacturing industry and the rise of the service industry.

There is however one element still missing from the historical epistemology of class, and that is morality and how it was articulated culturally. Definitions of class often encode ideas of a person's moral worth, and it is in the attribution of morality that the link is made to 'living' class and possibilities for identification. There have been certain periods when class was definable primarily by economic, monetary and market value; at others it was defined in relation to moral behaviour. During the 1850 s and 1860 s, for instance, there is less talk of working class and middle class, and more of deserving and undeserving poor, of "respectable artisans and "gentlemen", as emphasis was placed on moral rather than economic criteria' (Crossick, 1991: 61). It was in the play for legitimation that morality became central to defining class. Adam Smith, the proponent of political economy, for instance, advanced the concept of self-interest (and its according accrual of wealth) as a moral imperative, and the emergent bourgeoisie were concerned to legitimate their mercantile interests by differentiating themselves from the degenerate behaviour of aristocrats via the use of religious justification. ${ }^{1}$

However, it was not until the early nineteenth century that the term 'class' regularly appears in discourse and is consolidated in descriptions of society. Some theorists argue that the term class emerged to coincide with the rise of the 'middle sort' (Williams, 1988). Dror Wahrman (1995) maintains that the crucial moment for fixing the idea of the middle class was around the time of the Reform Act 1832 where the need for political representation allowed the middle class to be consolidated as a group. A central issue is who had access to the symbolic means to legitimate themselves in particular ways, and what resources they used to conceptualise themselves. Terry Eagleton notes how the middle class used the expression of 'taste' and the generation of distinctive cultures: 'the ultimate binding force of the bourgeois social order [were] habits, pieties, sentiments and affections' (1989: 22) by which they attributed higher moral value to themselves. The claims to high culture and taste continue to be a mechanism for promoting distinction and enabling the recognition of class positions (Bourdieu, 1984[1979]).

The emergence of the term working class is subject to a similarly contested debate. Lynette Finch (1993) documents how, in Australia, class emerged from the middleclass colonial welfare administrators as a category to define the urban poor. Carrying with them British definitions, she illustrates how they developed their own interpretations and categorisations that were particularly gendered, conceived through the interpretation of the behaviour of women of urban slums:

The range of chosen concerns through which middle-class observers made sense of the observed, included references to: living room conditions [...] drinking behaviour [...] language (including both the type of things which were spoken about, 
and the manner in which they were referred to literally the types of words used); and children's behaviour [...] (1993: 10)

As she notes, these were moral, gendered, references. In an equally detailed historical analysis of British imperial discourse, Ann McClintock suggests that the concept of class has an historical link to more generalisable 'others', who were known through the concept of degeneracy, a term applied as much to classifying racial 'types' as to the urban poor:

The degenerate classes, defined as departures from the normal human type, were as necessary to the self-definition of the middle-class as the idea of degeneration was to the idea of progress, for the distance along the path of progress travelled by some portions of humanity could be measured only by the distance others lagged behind. (1995: 46)

Domestic servants, for instance, were often depicted by the racialised imagery of degradation - of contagion, promiscuity and savagery. As Fredrick Engels notes of the working class: 'a physically degenerate race, robbed of all humanity, degraded, reduced morally and intellectually to bestiality' (1958[1844]: 33). What we see in Engels' comment is how a description, used in his case to advocate for social justice, is limited by the prevailing discourses of his time, which semiotically attach degeneracy to the working classes. In the bourgeois claim for moral legitimacy, domestic servants, in particular, became the projected object for dirt, and more explicitly were associated with the care of back passages ${ }^{2}$ and the generalised poor came to be represented as excrement. Osbourne's pamphlet on Excremental Sewage in 1852 represents the working-class as a problem for civilisation, as sewerage that contaminates and drains the nation (Yeo, 1993). However, hygiene became one of the first discourses to connect to marketing and commodities as a solution to the threat to the nation by those figured as decadent, degenerate and unhygienic: washing the nation clean offered a defence to the threatening pollution of race, class, gender and sexuality. Dirt and waste, sexuality and contagion, danger and disorder, degeneracy and pathology, became the moral evaluations by which the workingclass were coded and recorded in the representations of the day (Nead, 1988), not dissimilar to those reproduced today: Chris Haylett (2001) for instance notes how in the 1990 s in the UK the white, working class were increasingly coloured, coded as 'dirty white' in government rhetoric; as degenerate, atavistic and abject, surplus to the requirement of a vanguard bourgeois cosmopolitan nation.

Gender, race and sexuality amalgamate in all class definitions. As McClintock puts it, 'the invention of racial fetishism became central to the regime of sexual fetishism became central to the policing of the "dangerous classes"' (1995: 182). In most debates about the formation of class aristocratic women are seen to signal constitutive negative limits, particularly despiséd for their excessive and lascivious sexuality. Foucault argues that the middle-class, struggling to find the means to define themselves, used reference to commodification to regulate sexuality as a means of social identification:

The middle-class thus defined itself as different from the aristocracy and the working-classes who spent, sexually and economically, without moderation [...] It differed by virtue of its sexual restraint, its monogamy and its economic restraint or thrift'. (1979: 100)

When Foucault identifies the four discourses that came to produce sexuality (the Malthusian couple, the masturbating child, the hysterical woman, the perverse adult) we can see a similar process occurring with class. The discourses and figures of the dangerous outcast, the urban mass, the revolutionary alien, the contagious woman and the dirty degenerate came to produce what was known as working classness. The category of the contagious woman, figured through the prostitute, presented specific definitional problems. The paradox of needing to name, identify, quantify and know, also produced 
the possibility of breathing life into the figure, making it a lived possibility, and thereby provoking a range of questions about why and for whom the prostitute exists. The sexuality of working-class women became a source of desire and 'scientific' observation for the Victorian male reformers such as Malthus and Mumby, who tried to apply 'scientific methods' to the study of their objects of fascination. The association with sexuality did not offer any potential for identity; rather it was the absolute limit to it, to moral value. However, the outcome of this projected exclusion was to make the limit the site of all that was interesting and potentially desirable. Hence the long obsession with black and white, working-class danger and sexuality when the middle class engage in class-tourism, 'poorism' or affect-stripping. ${ }^{3}$

These perspectives on race and sexuality produced in the interests of consolidating the legitimation of powerful groups via quantification, empirical observation and moral attribution, came to institutionalise class in very specific ways associated with governance and economy. Vron Ware (1992), for instance, shows how British abolition struggles cannot be understood without connecting sexuality, race and class with their national formation, which then takes on a transnational significance. The entwining of race and class was particularly central to the shaping of contemporary racial politics in the UK (and Angela Davis would argue, the US). Take Hall et al.'s comment:

It is through the modality of race that blacks comprehend, handle and then begin to resist the exploitation which is an objective feature of their class situation. Race is therefore not only an element of the 'structures'; it is a key element of the class struggle - and thus in the cultures of black labour. (Hall, Critcher et al. 1978: 347)

The processes of historical de-legitimation and de-subjectification work across different forms of categorisation to de/attach value to subjects. Yet the connections made through categorical relations are not ones of equivalence. They operate with very different logics. Connected constitution does not mean that there is a correspondence between categories. ${ }^{4}$ Neither does 'being classed' (being classified and positioned by others) equate with taking up an identity. Zizek (2004) notes that there is a fundamental difference between the goals of identity groups (those who willingly make an identification that can be recognised to make public claims for legitimacy) and class struggle. The goal of identity groups is to translate antagonism into difference, whilst the goal of class struggle is precisely the opposite: to aggravate class difference into class antagonism. To set up a series of equivalences between race, gender and class is to obscure the peculiar logic of class struggle, which aims at overcoming, subduing, even annihilating the other. ${ }^{5}$ In one case, we have a horizontal logic involving mutual recognition among different identities; in the other we have the logic of struggle with an antagonist. A similar division exists between the assimilationist aspirations of multiculturalists and the vertical logic of anti-racism. Zizek notes that the contemporary paradox is that populist fundamentalists (he refers specifically to the conservative fundamentalists in the US whose rhetoric was widely deployed by the Republican party in the GW Bush election campaign) retain this logic of antagonism while the liberal left persists with the logic of the recognition of differences (see later).

\section{RECOGNITION AND PERFORMATIVITY}

Drawing on the work of Austin (1962) and making an argument similar to that of Judith Butler (1999), Bourdieu (1992) ${ }^{6}$ argues that theory is performative, bringing into effect that which it names. He aims to challenge descriptions that consist in treating classes on paper as real classes, which he identifies as a 'theoreticist error'. ${ }^{7}$ Metaphors, he argues, allows us to move beyond the alternatives of realism and nominalism, enabling us to make abstractions about social 
relations and to think about how they are 'made'. He notes:

\begin{abstract}
The title of E.P. Thompson's book The Making of the English Working Class must be taken quite literally; the working class such as it appears to us today through the words meant to designate it, 'working class', 'proletariat', 'workers', 'labour movement', and so on, through the organisations that are supposed to express its will, through the logos, bureaus, locals, flags, etc., is a well founded historical artefact. (Bourdieu, 1989: 18)
\end{abstract}

Class as a performative classification brings the perspective of the classifier into effect in two ways: first, to confirm the perspective of the classifier; and, second, to capture the classified within discourse. As Bourdieu notes 'nothing classifies somebody more than the way he or she classifies' (1989: 19). Whether we opt to understand class as a symptom of exploitation and political struggle or as a matter of hierarchy and classification says more about us (the classifier and our identifications) than those who may be subject to the very material effects of the classification.

However, in all of these debates over definition, as Finch (1993) documents, the working class (the classified) did not identify with the value-laden content of the classification, as degenerate, dangerous, lascivious and/or contagious. Rather, they operated with different value systems (as E.P. Thompson [1966] and Martha Vicinus [1974] demonstrate). Yet not having access to the symbolic systems of representation they were unable to directly challenge the negative classifications and positioning of themselves. So while huge amounts of energy were put into defining, knowing, classifying, recognising and moralising the working class, they went about their business using their own evaluations and deriding displays of moral authority that condemned them. ${ }^{8}$ That is, until, as E.P Thompson notes, they learnt to politically organise around the term. The term working class came to have increasing significance for trade union organising (Marx's combination groups, such as the Chartists) and the formation of political parties (the British Labour Party), offering a space for identification for those who could join, and there are substantive debates about the exclusion of women from trade union campaigns through the rhetorical gendered claims of the 'male breadwinner' (Brenner and Ramas, 1984). But another way in which the working class 'combined', which is often overlooked, is through their demands for decadence, for fun and pleasure; a necessary defence, Zizek (2000) argues, against the grim conditions endured. Through fun and pleasure they also found alternative ways of challenging the legitimacy of the classifiers. Vicinus reveals how the working class reversed moral judgements by heaping scorn on those with pretensions to gentility, by laughing at those who restrained their own pleasure and by deriding those who tried to occupy the moral high ground: 'Putting on airs was the greatest sin anyone could commit' (1974: 262-3). A statement still found in contemporary research on class relations (Walkerdine and Lucey, 1989). Music hall and contemporary entertainment dramatise a class struggle in which the working class challenge the moral authority that seeks to condemn them.

The attempts to make the working class recognise their classification is also noted by Carolyn Steedman $(1999,2000)$ who introduces an important factor into the performative emergence of the category class. She traces how a working-class self as a moral categorisation, came into existence through the religious discourse of redemption, a self that had to be respectable and prove itself to be capable of narrating itself in the ways established by the state-legal interlocutor systems of poor relief. If the Reform Law (political representation structured through property ownership) was key to the formation of the middle class, the Poor Law (basic economic subsistence) was significant to the establishment of the working class. In these differentially invested and incited formations: one that makes political claims for legitimated legal property ownership and one that is forced to perform a category in order 
to stay alive, class difference is historically shaped. In all of these classification processes, as we have seen, class is in continual constitution, not just through other classifications but also through the concepts we use, which appear as neutral.

This is particularly pertinent in relation to how debates about personhood develop into ideas about the individual, the self and identity. It is very difficult to speak about "the self' without introducing the whole historical baggage of classed history that enabled the concept of the self to come into existence in the conceptual shape that is used today. And because of the close link between identity and self - where identity is seen to be central to self-formation, it is worth discussing how class relations shape the self. Briefly, the idea of the self developed from the discourse of possessive individualism, the cornerstone of seventeenth-century political theory (Macpherson, 1962). Marilyn Strathern (1992) documents how the concept of the 'possessive individual' (that is a person who is defined through his capacity to own property in his person) developed from the perspective of an elite property holding small group, with access to circuits of symbolic distribution who were able to legitimate their own interests and establish their own authority by defining themselves against the 'mass', as the constitutive limit for what an individual could be. The perspective of the 'possessive individual' was replicated in various different ways and institutionalized in law, via property relations and the development of concepts of rights-bearing individuals (this is, of course, a very shorthand and reductive story, see (Skeggs, 2004) [2004] for a book-length account). What was central to the reproduction of the possessive individual was how particular techniques such as narrative, biography and scientific discourse, were used to legitimate interest: the heroic individual and the civilised person were consolidated as identity spaces through the promotion of the rhetoric of advanced civilisation established by eugenics. By institutionalising themselves, not just through law, but through different systems of knowledge, the middle class were able to consolidate their interests across a variety of fields. These different relationships to property and their legitimation leave long legacies for understanding who is classified as having the potential to become an individual, a civilised person, a valued national citizen, and who can defend these positions in law and hence who can make recognition claims through identity on the nation-state and beyond. ${ }^{9}$

\section{CONTEMPORARY CLASS FORMATIONS}

The study of class always takes a particularly national formation, which as Philip Kelly (2007) argues is one of its limits. In Britain, Mike Savage (2000) illustrates how analysis of class worked as a means by which British social scientists identified their distinctive expertise vis-à-vis other national traditions. Drawing on long historical traditions for studying the social and deploying established techniques (such as measurement, hierarchy and labour, as described above) Savage identifies how debates in the UK and US revolved around how to conceptualise the 'social', for example, as conglomerates of individuals or as structures of power, which usually conflated with 'social class'. He shows how the 'political arithmetic technique' diversified into new fields, such as social policy, welfare and education, which were all nationally specific. Also, the conflict identified in class relations took specific forms, with a strong Marxist line in the UK, and a functionalist one in the US. As a concept class also took on a national tone that traversed academic boundaries and entered the popular becoming a site of wider political debate. Class relations also became the foundation by which national social change was measured, often through comparative studies where comparison was used to highlight the specificities of the nation (Wright, 1985). 
We can see this in contemporary debates about post-Fordism, de-traditionalisation and disorganised capital, where in an attempt to understand social formation and social change, class becomes a structuring absence, that which is being moved from and thus is the baseline of the movement, hence terms such as post-, de- and dis- mark the movement from a focus on class formations, while echoing their presence.

As a concept class is, therefore, being used to do many things: classify and legitimate inequalities, provide academic legitimacy, frame an academic discipline, speak to 'the people', measure social change, explain national formation and stand in for the social itself. It is hardly surprising then, that it stubbornly remains as a concept after all the attempts to retreat from it, deny it, refigure it, dismiss it, trivialise it and de-centre it. For, as Cannadine notes, 'the history of class is as much about the history of ideas about society as it is about society itself' (1998: 171).

Within ideas about society are contained ideas about the possibility of identity and identification. As we have seen, a category has to exist for an identification to be made, for an identity to be created and inhabited. One important recent development in class analysis has been the work of Pierre Bourdieu, who brings together elements of the trajectories identified: exploitation, measurement and morality to understand how class is shaped by access to different capitals which over time become literally embodied as a class habitus.

Bourdieu (1979, 1985 and 1987) develops a model of social topography to demonstrate how relative positions and the relations between these positions constitute forms of power, enabling bodies to move in social space. Bourdieu identifies four main types of capital: economic, cultural, social, and symbolic:

- Economic capital - includes income, wealth, financial inheritances, and monetary assets: what you own.
- Cultural capital - this can exist in three forms: in an embodied state, that is, in the form of long lasting dispositions of the mind and the body; in the objectified state, in the form of cultural goods; and in the institutionalized state, resulting in such things as educational qualifications. Bourdieu defines cultural capital as high culture.

- Social capital - resources based on connection, networks and group membership: who you know, used in pursuit of favour and advancement.

- Symbolic capital - the form the different types of capital take once they are perceived and recognised as legitimate. Legitimation is the key mechanism in the conversion to power. Cultural capital has to be legitimated before it can have symbolic power. Capital has to be regarded as legitimate before it can be capitalised upon, before its value is realisable.

People are distributed in social space according to: the global volume of capital they posses; the composition of their capital, evolution of the volume and composition according to their trajectory in social space. It is not just the volume and composition of the right sort of cultural capital (for national belonging), but it is also how one accumulates it that makes an important difference to its capacity to be converted. Bourdieu distinguishes between those who only have to be what they are as opposed to those who are what they do and, therefore, have to constantly prove that they are capable of carrying symbolic value.

Taste is the most obvious manifestation of this process, whereby access to high culture enables people to develop dispositions and knowledge over time (refined and distanced contemplation for instance as opposed to expressions of direct hedonism). The ability to accrue high culture dispositions depends on exposure to social spaces, what he calls 'fields', abstract spaces in which the forces of history cohere, where battles for value and legitimacy are fought and where different forms of capital are converted (or not) into value over time. The symbolic system creates, circulates and maintains distinctions from the perspective and interest of those with power (symbolic capital), enabling them 
to accrue value to themselves whilst keeping others contained in social spaces with little prospect of conversion, unable to access the capitals that have value to enable social movement to occur. I will now develop this analysis through some ethnographic research I conducted over a period of 11 years to show how the possibilities for identification work through the different legacies and logics, shaped by gender and class.

\section{AFFECTIVE MORAL CLASS ANTAGONISMS}

My research showed how, for a group of white, working-class women from the north of England, processes of mis-recognition shape their responses to identity formation; they dis-identify from the term working class, which only offers the possibility of pathology. They literally stand in discomfort under a sign that has no meaning for them; instead positioning themselves with value. The women were identified sociologically as working class, that is, by a range of different social measures and cultural practices (see Formations of Class and Gender [Skeggs, 1997]). They did not want to be identified as working class, and certainly did not occupy a working-class identity, a reaction whose logic became apparent during the course of the longitudinal research, and enabled me to think through the usefulness of the term identity when put together with class.

Immersed in the lives and spaces of these women over time I became highly conscious of the numerous ways in which they were constantly subject to negative value judgements, about their futures and pasts, behaviour, intelligence, taste, bodies and sexuality, to such an extent that it shaped their spatial sense of entitlement, engagement and limit: where they did or did not want to go. The women were not strongly visibly marked as excessive, loud, dirty or dangerous, yet 'being looked down on' was their description of a process to which they were continually subject, a visual assessment by others that repeatedly positioned them as lacking value. For instance, when they entered 'posh shops' Wendy notes how they were acutely aware of being read and judged by others:

We'd all gone up to Manchester the other Saturday, you know for a day out, the three of us ... We were in Kendals during the day, you know where the really posh food is, and we were laughing about all the chocolates and how many we could eat - if we could afford them- and this woman she just looked at us. If looks could kill. Like we were only standing there. We weren't doing anything wrong. We weren't scruffy or anything. She just looked. It was like it was her place and we didn't belong there. And you know what? We just all walked away. We should have punched her in the face. We didn't say anything until about half an hour later. Can you imagine? Well and truly put in our place ... It's things like that that put you off going. You feel better staying around here. (Wendy, 1986)

The gaze that embodies the symbolic reading of the women makes them feel 'out of place', thereby generating a sense of where their 'place' should be. Here they are not called directly into effect, a performative interpellation into identity, but indirectly, through a defensive reaction to the judgement. This makes the classification of class operate as a negative structuring absence, not a positive source of identification.

The shop assistants gaze is a judgement of taste, ${ }^{10}$ with spatial consequences, which classifies the classifier as much as the classified. It displays the repetition of the 'hidden injury' identified by Richard Sennett (1977). However, even though this gaze resulted in a desire to return to the safety of 'one's place', such readings were not always accepted:

That's like when you're walking through the perfume bit of Owen and Owen [department store] and they're spraying perfume all over the posh ones and you know you're not going to get any. Me and Jane, we used to stand there till she sprayed us. (Morag, 1986) ${ }^{1}$

This defensive response displays a refusal to stay in, or be put in, place by others. But it is a constant struggle to continually deflect the negative connotations. For Morag, Yvonne, Ann and Wendy, working class is not an 


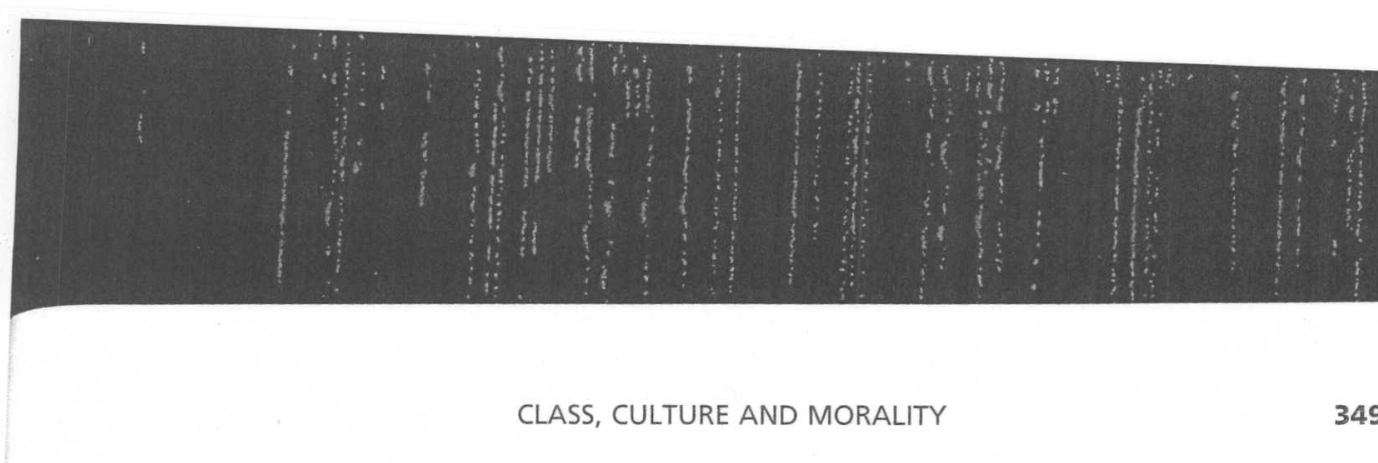

identity that is taken up in relation to a positive recognition, but an awareness of negative judgements. As Yvonne notes:

All my life I've wanted to say 'look I'm as good as you', well now I think this house says it. It says 'I've made it, I'm respectable and you can't put me down'. (1992)

And Anne talks of how every decision is a matter of assessment in trying to deflect the negative evaluations of others:

All the time you've got to weigh everything up: is it too tarty? Will I look like a right slag in it? What will people think? It drives me mad that every time you go to put your clothes on you have to think do I look dead common? Is it rough? Do I look like a dog?

When I grew up my mother was (and even now in her eighties, still is) obsessed with the fear of 'looking common'. To be identified as common was one of the worst things that could happen to her: 'mortifying' she would say in a very visible rendition of spatial containment. Re-signification of the term was attempted so that 'common tart' became a humorous amelioration, but only if spoken by those subject to similar judgements. For the term common was (and still is), shorthand for a middle-class taste judgement that says 'worthless', without directly betraying the perspective and position of the judger as a privileged snob.

As Andrew Sayer (2005) notes, moral boundary drawing and value attribution treats the merits claimed for the judging group as if universally valid. He describes how the middle class rarely want to acknowledge the privileged social and economic position from which they speak, displaying embarrassment and evasion, often denying the significance of class, or individualising difference, responses which he suggests indicate an awareness that class differences lack moral justification. Sayer points to the moral significance of class, precisely because it cannot be divorced from attributions of worth and person-value, creating unequal possibilities for flourishing and suffering. This is more than identity; it is ontology, the conditions for the possibilities for living.
If we add Spinoza's (1996) theory of affect to Bourdieu's spatial metaphors, we can see how what he terms 'the force of existing' is in a continuous variation. Spinoza, writing in the sixteenth century, maintains that when we come across somebody good, if they make us joyful, they increase our capacity/ ability to act, whereas if we meet sadness inhibition increases and decreases our capacity to act. Spinoza was concerned to understand how people with power use sadness to affect us to increase their power and decrease the power of others (he studied priests). This continual variation experienced through social encounters: increase-diminutionincrease-diminution, Spinoza defines as affective movement. I would argue that the repeated attachment of negative value to the working class intensifies and increases diminution. This is not limited to individualised social encounters but how our total social relations are shaped through this process; affects arise from within the system of social relationships, institutions and practices that exceed individuals. When one enters a social encounter with an awareness of the possibilities for denigration, a defensive response to the potential negative evaluation is prepared.

Spinoza also notes how continuous variation in the force of existing is determined by the ideas one gives to the affects we feel. So if we feel diminished we may look for an idea to explain our detumescence. If we look to the category of working class to explain our negative evaluation, we may either be able to convert it into something positive, such as trade union activity, or may generate distance from it in order to protect ourselves from its negative effects (feeling, sad, diminished and out of place). Likewise, if diminished by class we may be able to protect our value through other classificatory systems such as sexuality, gender or race which have different potentials for re-signification and value attachment (for example, 'black and proud' or 'queer and here'). Thus the encounter is a dialectical movement of value, whereby one may establish value at the cost of another; hence why judgements of
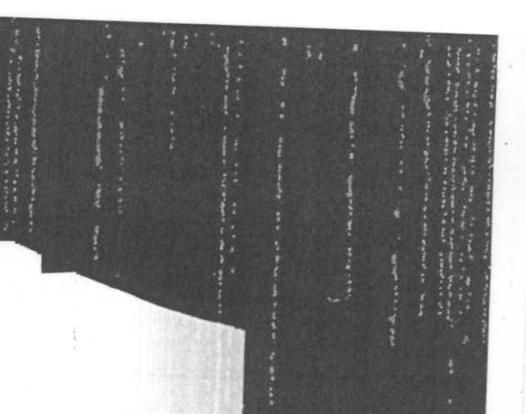
taste and classification are considered by Bourdieu to be acts of symbolic violence:

If there is any terrorism it is in the peremptory verdicts which, in the name of taste, condemn to ridicule, indignity, shame, silence [...] men and women who simply fall short, in the eyes of their judges, of the right way of being and doing. (1986: 511)

The women's responses above demonstrate a clear understanding of the ideas by which they are positioned: 'they think we're shit', a point on which the majority of teachers agreed expressing: 'there's no point educating them, they'll only have hundreds of babies'. The women's responses are an understanding of person-value. They know that being recognised as working-class has led to their devaluation, which is too negatively loaded for re-signification. This is why these understandings rarely produce a consciousness that leads to positive collective class identification, but instead to the desire to have and be seen to have value, constantly morally mediated.

The fear of being judged shaped how the women, literally and metaphorically, moved through social space: they apologised for failure at school, for not having immaculately clean houses (which they did have), not having brand new furniture, for the wrong bodies, living in the wrong area, liking the wrong music, wearing the wrong clothes (see Formations). As Annette Kuhn notes:

Class is not just about the way you talk, or dress, or furnish your home; it is not just about the job you do or how much money you make doing it; nor is it merely about whether or not you have $A$ levels or went to university, nor which university you went to. Class is something beneath your clothes, under your skin, in your reflexes, in your psyche, at the very core of your being. In the all-encompassing English class system, if you know that you are in the 'wrong' class, you know that therefore you are a valueless person. (1995: 98)

Kuhn clearly identifies the way repeated negative evaluations become lived 'at the very core of being' as a form of ontological insecurity which produced in the women of my research constant surveillance of them- selves and the development of strategies to gain value. By condemning people for not being able to 'look right', 'do it right' or 'be right', responsibility is attributed to them for something which is determined by 'an accident of birth', their inheritance of and exposure to economic, cultural, symbolic and social capital and also for the negative affect they encounter.

I argued, as a result of the research findings that this group of working-class women dis-identified from class positioning and class identity; ideas which only attached negative value to them. They did not want to be recognized as working-class because for them that recognition always involved mis-recognition; that is, they were read constantly as something they were not (worthless) and accordingly diminished.

However, the ideas they attach to their experience of diminution are the result of class relations, about unfairness and injustice, the difficulty of challenging negative value and the attempt to gain moral high ground. Julie outlines her ideas in a discussion of 'dressing down':

\begin{abstract}
Yea, I've seen that in Alderly Edge with the younger ones. I guess it's because they're students and they are trying to show how clever and bohemian they are. But it is really clever because like if you were poor or at least not very well off you wouldn't dare look that scruffy because everybody would know just how little money you had so it's really only the very rich who can get away with it. What I mean is it's just like another way of maintaining differences between groups. You have to be really rich to be really scruffy or else you'd feel really bad and be dead ashamed of yourself but they're not, they get away with it. (1992)
\end{abstract}

Or when directly speaking about the middle class:

When I first went to work as a nanny I couldn't stand it. They really think they're something else. They treat you like shit. What I've noticed is they never look at you. Well they do at first they look you all over and make you feel like a door rag, but then they just tell you what to do. Some of them want you to know you're shit in comparison to them. I jacked it in shit money, being made to feel like shit. Even the kids. They learn really early that 
you're not worth the ground they walk on. They're bastards. (Cynthia, 1992)

They always assume they have a right to anything and everything. It's like whatever they are doing that's their right. They just think the world is made for them. (Angela, 1989)

Julie, Cynthia and Angela have a strong sense of class positioning and how they are positioned without worth and how others position themselves with entitlement. And whilst the women desperately desire to gain respect, have value and be taken seriously this does not mean that they aspire to be middle class. As Cynthia and Angela articulate, the middle class behaves in ways of which Cynthia and Angela do not approve. The research was suffused with comments of awareness, affects of resentment and derision: class antagonism expressed loudly:

It's the way they think they know about things all the time. Sue's (her sister) brother in law is a scream. He sits there pontificating. Talking absolute shite about everything. I just think he's a dickhead. We all do. Everyone takes the piss out of him. (Cindy, 1989)

They come into the restaurant ordering things in a hoity toity manner. They're really ignorant. It's fucking pizzas for Christ sakes. We'd put snot on their pizzas - you can never tell, and they're usually dead stingy with the tips. You can always tell the rich ones, they keep hold of their money (Rachel, 1986)

What gets me about these people with loads of money is they look crap. They haven't a clue about style, about what to wear, about how to put things together. If I had that much money I'd look fucking brilliant. (Cynthia, 1992)

These are strong statements of anger, of moral indignation. Other research shows these feelings are mutual with the middle classes making equally derisory comments (Frazer, 1992; Lawler, 2002; Ortner, 1991; Walkerdine et al., 2001). Yet there is a difference in the intensity and type of the affects expressed, with anger, frustration, resentment and indignation appearing as more vehement expressions than the derision, disgust and contempt of the middle class. The proximity to legitimacy (what Bourdieu calls symbolic capital) defines which affects are represented as a legitimate response, while others are represented as irrational and/or excessive. Affects exist within a circuit of symbolic value that legitimates their expression: for instance, Steph Lawler (2002) notes how two protests in the UK, both against registered sex-offenders living in a community (similar to Megan's Law in the US), were attributed with a different legitimacy depending on who performed the protest. The middle-class mothers were presented in the national press as devoted and vigilant, as a worried 'we' who were right to be concerned about 'our' (the nation's) children, enabling a general moral identification to be made, unlike the working-class women (known as the Paulsgrove protesters) who were vilified as a mob, ignorant, threatening, repulsive and horrific, vigilante rather than vigilant.

The negative value and affects attached to the Paulsgrove women, however tells us more about the journalists' class-based obsessions and fears than those of the protestors. Elsewhere I have mapped the extraordinary fascination with and hatred of working-class culture by middle-class commentators, resulting in terms such as 'chav' in the UK (the Oxford English Dictionary 2004 word of the year ${ }^{12}$ ), visualised on the Chavscum.com website. A site where 'the hatred almost explodes off the computer screen', a comment made by the ex-Conservative party advisor, Ferdinand Mount who describes its content as 'weird loathing' and 'vile caricatures' (2004: 90). In his most recent book, on class, he remarks:

What I do not think many people have yet woken up to is that the working class has been subjected to a sustained programme of social contempt and institutional erosion which has persisted through many different governments and several political fashions. (2004: 273)

As ex-head of Margaret Thatcher's Number Ten Policy Unit (responsible for creating class inequalities), he charts, but expresses surprise at, the 'bad manners' and vulgarity of the middle classes who now feel it is legitimate to display their hatred of the working class so blatantly. Legal theorist, 
David Garland demonstrates how it is not just institutional erosion but the institutionalisation of hate in criminal law that since the 1980s punishes a working class that is seen to be beyond redemption, without the possibility of rehabilitation (Ruddick, 2006).

Even if the working class feel anger, resentment and hate, it is unlikely that their expression of these emotions will be given legitimacy - they are more likely to be criminalised for their expression. Yet the same expressions by the middle class may be institutionalised. Sara Ahmed (2004) suggests that we inhabit an affective economy where hate is economic; that is hate circulates between signifiers in relationships of difference and displacement and is distributed across a variety of figures where through the process of what she calls 'metonymic slide' figures such as 'chavs' (and in her example of 'asylum seekers', a highly racialised negative term in the UK) become readable as nationally cancerous, as rotting the moral fabric of the nation. Hate, she maintains, cannot be found just in one figure, but works to create the very outline of different figures or objects of hate, a creation that crucially aligns the figures together and constitutes them as a 'common' threat, but with different intensities (for example, the female and male 'chav'). In such affective economies, she argues, emotions do things, they align individuals with communities - or bodily space with social space - through the very intensity of their attachments. What we see in the UK through the expression of such unadulterated contempt is a public alignment of middle-class values against working-class lifestyles. The affects of antagonism become central to how people express their social relations and to how people are recognised, evaluated and legitimated. The circulation of negative affects, just like the values they accompany are deflected by the working class through the reversal of the judgement: they define the middle class as ignorant, clueless, stupid, tight and badly dressed. This reversal becomes particularly acute around issues of childcare:

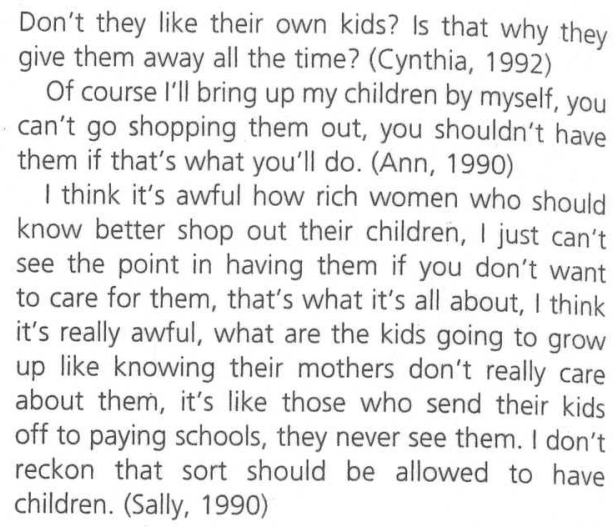

Don't they like their own kids? Is that why they give them away all the time? (Cynthia, 1992)

Of course I'll bring up my children by myself, you can't go shopping them out, you shouldn't have them if that's what you'll do. (Ann, 1990)

I think it's awful how rich women who should know better shop out their children, I just can't see the point in having them if you don't want to care for them, that's what it's all about, I think it's really awful, what are the kids going to grow up like knowing their mothers don't really care about them, it's like those who send their kids off to paying schools, they never see them. I don't reckon that sort should be allowed to have children. (Sally, 1990)

By claiming themselves to be the real and proper mothers they invert class divisions and claim moral superiority over the middle-class women, who by 'shopping out' their children reveal themselves to be uncaring, unnatural, irresponsible and ultimately immoral. This inversion of value has also been documented in other research on motherhood (Duncan, 2005; Lawler, 2000; Reay, 1998) and child development (Walkerdine and Lucey, 1989). What we see is a continual struggle over legitimacy to judge value, experienced affectively and expressed here through the moral discourse of eugenics.

\section{MOBILISING MORAL VALUE}

Moral legitimacy pervades not just everyday experience but also theoretical descriptions. John Kirk (2007) investigates those who make strong claims for the cultural significance of English, northern, workingclass cultures, but who paradoxically proceed to map this culture's disappearance; a paradox he suggests produced by a nostalgic belief in the 'then' of industrialism and the 'now' of consumerism, where the past is described as a moral economy of solidarity and collective care. Kirk carefully interrogates two texts which make this textual move of past/present: Richard Hoggart (1957) and 
Simon Charlesworth (2000), noting how Hoggart's period of cultural deficit and the decline of collective class culture from the late 1950 s to the 1970 s represents the golden years for Charlesworth's past/present, a time before the onslaught of Thatcherism and industrial decline. Charlesworth vividly describes a tragic structure of feeling of the dispossessed, where being in the world is a matter of lack, deprivation and loss, compensated for by the useless consolations of commodity desire, a similar description to Hoggart's 1950s 'candy floss world' in which mass entertainments are full of corrupt brightness, improper appeals and moral evasions. As Kirk points out, both offer two victims in the present: the working-class and its selfidentity. Both identify the inadequacies of the people to generate meaning beyond commodity driven pleasure. He notes how for both Hoggart and Charlesworth: 'the sense of no longer holding a coherent narrative of one's being in the world, of not possessing the symbolic freight or the cultural capital to compete or to participate in social life, render these working-class people mute' (2007: 35), lacking in personal resources colonised by the commodity form in which commodity desire replaces common identity.

These representations of the working class as tragically mute, or commodity dupes, contrasts with not only the loud antagonisms expressed above but also with the studies of working-class boys as infinitely creative within their cramped spaces. Paul Willis (1977) notes the hedonism, excitement and defiance of authority achieved by inverting the school's core values. Drawing on American sub-culture theory from the 1950 s (Cohen, 1955) he shows how boys disengage themselves from the schools rituals and values and re-orientate themselves instead around leisure activities. Walter Miller (1958) suggests that their behaviour is not an inversion as such, but represents the focal concerns of masculine working-class culture - excitement, toughness and luck. Values, which David Matza (1964) suggests, are also one part of the dominant culture and other class factions. This 'creative' analysis shows how dominant values are inverted but very differently in terms of gender, If we apply Bourdieu's multiple capitals theory we can see how gender cuts through this re-valuation process: irresponsibility for young men, responsibility for young women. (Although I'd argue that excitement, recreation and hedonism have also been part of young women's culture, often but not always, curtailed by family responsibilities.)

The displays of working-class, masculine identity premised on irreverence, ultimately fitted Willis's 'lads' back into the world of industrial labour via gender by inverting the binary of mental and manual to reposition themselves as the ones with hard masculine value; yet hard masculinity is precisely what the hard industrial factory required (the research was in the mid 1970s). But Willis's research is a study of challenges to authority via culture rather than challenges to capitalism. A point amplified by contemporary research, which examines what happens to the working class when traditional work conditions are destroyed and gender becomes detached from the traditional sexual division of labour. Lois Weis's (2004) longitudinal ethnography of the transition of 'Freeway' from an industrial steel town to a restructured service economy, demonstrates how a considerable amount of class, race and gender re-embedding occurs, with redundant men no longer able to fulfil their 'hard work' ethos or deal with domesticity. The women become more resourceful and creative in dealing with the new conditions, suggesting that irreverence and inversion are highly specific responses to the conditions of their own creation; creation within changing capitalist relations.

The search for dignity beyond work, for value in conditions of devaluation, by both men and women, black and white, has also been charted by Mitch Duneier (1992) who illustrated how a group of black men in Chicago desired to be recognised as respectable not as dangerous, criminal or pathological, which (like the women of the 
Formations research) was often how they were misrecognised and diminished in social encounters. ${ }^{13}$ Likewise, Michelle Lamont (2000) identifies a distinct moral code focusing on personal integrity and the quality of interpersonal relationships ${ }^{14}$ among both white and black, working-class men to whom she spoke; they too did not want to become middle class. These were not responses of radical creativity (Willis) or antagonistic moral inversion (Skeggs) but straightforward attempts to claim worth and value for themselves. These studies, however, also point to the lack of antagonism present in generalised American class discourse and American cultural theory, what bell hooks calls 'the elephant in the room' - the unnamed subject that everybody knows is central to their lives but cannot be named as such; instead: 'Race and gender are used as screens to deflect attention away from the harsh realities that class politics exposes' (2000: 7).

Mobilisation of moral value as part of a class struggle is not straightforward. Tom Frank (2004) notes how in the US in the 1990s a disaffected, unemployed, male, working class were persuaded through antiliberal populist public outrage rhetoric to elevate 'morality' via the protection of the family and the foetus, and in so doing align themselves with a Republican Right that promoted the interests of the super-rich. ${ }^{15}$ Part of the Republicans' rhetorical appeal was its ability to detach already formed moral values such as unpretentiousness, authenticity, hard work and loyalty from the conditions of their original production (working-class life), a space which was increasingly entrenched, and re-attach them to the interests of an imaginary safe and secure prosperous rightwing nation through the promise of respect and respectability. That the rhetorical struggle was able to insert middle-class pretentiousness - a bilingual, French-speaking liberal elite with French culinary taste came under particular attack - as an already established yet unspoken source of antagonism, what Frank calls class animus, gave space to that which could not previously be spoken, class war and the 'elephant in the room' was split into two figures: the liberal middle class versus the moral working class.

Affect is put to powerful effect in the right-wing rhetoric describing liberals as arrogant, despicable, self-important show-offs, in short, 'snobs', who:

[...] [p]romote immoral destructive behaviour because they are snobs, they embrace criminals because they are snobs, they oppose tax cuts because they are snobs, they adore the environment because they are snobs. (Coulter, 2002: 27-9)

The aim of such rhetoric, Frank maintains, was to generate indignation by voicing the fury of the imposed upon, enabling diminished subjects to voice their indignation, not just through claims to respectability but by revenge: deriding the denigrators. Contempt returns to contempt. Cultural grievances and the challenges to authority are given national space and credibility, but the projected target has moved. It is class war of a kind but the alliance is not made with members of the same class, those of the same social position, but the powerful, those who put the grieved into the cramped spaces in the first place, from where they now speak back. This, I would argue, is not about identity, although the mobilisation occurs through its terms against a figure of identity (the liberal middle class), but about projected fantasies where inequalities disappear and justice is achieved.

What we see from these different political mobilisations is how they are premised on already structured class relations by which class antagonism can be activated. The working-class men identified by Frank in Kansas were ripe for recruitment to moral causes, such as protecting the foetus, because if offered them moral value while visualising and naming an enemy that fitted their already existing class antagonisms based on their experience of inequality, injustice and experience of diminishing value. Their grievances were detached from source and they were offered an affective fantasy of revenge to which they attached themselves, for a time. 
The moral struggles of the women of my ethnography are like microcosm of this process; they live the antagonism and the diminishing, struggling to gain moral value through motherhood and respectability in an attempt to make their lives bearable and value-full. Unlike the Kansas men they have not been mobilised around the visualisation of an enemy, instead they engage in minor battles in cramped spaces on a daily basis. In 2009 Barak Obama also mobilised affect but this time of a positive kind - hope. In the midst of national negativity he was able to propose the potential of a better future. In this political imaginary grievance take a different shape, attached to the positive future rather than the negative past. Local and national affects are the ways in which the experience of structural inequality attach to mechanisms for the creation of personvalue.

What we see in all the working-class ethnographies (from early sub-culture theory to the contemporary, through race and gender) is a desire to be recognised as having value, and thereby not denigrated, when one is repeatedly symbolically positioned as valueless. As respondents from another research project kept repeating to me 'it's so unfair to be punished for something which is an accident of birth'. ${ }^{16}$ Inequality and injustice is felt more intensely when people are blamed or cast as immoral for that into which they were born.

That a logic of antagonism underpins all class relations makes sense when we see how people have to live the devaluation process on a daily basis, not just through unequal access to resources, but also through diminishing and humiliation. What the antagonism displays is a resentment against unequal and unjust power structures and those who put them into effect. This is why identity does not offer enough explanatory power for the way class shapes lives: class is a product of capitalism, an archaeological structure of inequalities and antagonisms that can be hailed and lived in different ways (but always as forms of inequality distributing different types of unequal value). It is difficult for the working-class to gain economic equality (as history shows), but the claim to moral value is one way in which inequalities can be partially assuaged, in which value can be gained and judgement challenged.

\section{CONCLUSION}

Different discourses have defined class: socialism, moral reform, taxation, political representation and individualism, all representing different interests over time and space, and performatively bringing into effect different figures such as the degenerate, contagious, dangerous and, rarely, heroic. Moreover, the inheritance of class relations shapes the likelihood of entry into positivenegative value economies, into the possibilities for accruing and converting different forms of capital. The complexity of this process cannot be accounted for by the term 'identity'. Just as Butler notes in relation to the category 'woman':

\begin{abstract}
If 'women' within political discourse can never fully describe that which it names, that is neither because the category simply refers without describing nor because 'women' are the lost referent, that which 'does not exist', but because the term marks a dense intersection of social relations that cannot be summarised through the terms of identity. (1993: 218)
\end{abstract}

Exactly the same process applies for class. Class is a relationship between people who inherit not just different categories, but also who inherit the values of those categories, the inequalities and injustices. To inherit inequalities which are then symbolically repeated as if a measure of a person leads to justifiable resentments.

If Wendy Brown is correct in her observation that 'the political purchase of contemporary American identity politics would seem to be achieved in part through a certain re-naturalisation of capitalism' (1995: 60) then it makes total sense that those who are subject to the ravages and most brutal forms 
of exploitation by capitalism cannot make identity work for them. If identity politics works through making 'claims' on capitalism and the state for recognition, how can recognition be mobilised by those who are continually misrecognised and do not have access to circuits of symbolic value in order to socially adjust their value attribution. Those who have been most successful in the deployment of identity claims are those who have the highest consumer potential for capital, for example, women and gay men, as Rosemary Hennesey (2000) and Denis Altman (2001) show, or in the opening out of new markets through the branding of a bland multi-culturalism (that stands in opposition to antagonistic anti-racism) and extends the reach of late capitalism, as Zizek (1997) demonstrates. Brown asks:

To what extent do identity politics require a standard internal to existing society against which to pitch their claims, a standard that not only preserves capitalism from critique, but sustains the invisibility and inarticulateness of class - not incidentally, but endemically? Could we have stumbled upon one reason why class is invariably named but rarely theorised or developed in the multi-culturalist mantra, 'race, class, gender, sexuality? (1995: 61)

Zizek suggests that the almost impossibility of deploying identity politics anymore to class is not just about making-claims but is a much more powerful example of the political occlusion of class (in which social theorists are complicit when suggesting class decline): 'when class antagonism is disavowed, when its key structuring role is suspended, we are dealing with an exemplary case of the mechanism of ideological displacement' (2000: 97). A process we saw explicitly through the different ways in which affects can be mobilized with the 'right' fantasy of revenge and hope.

When class antagonism goes unremarked 'other markers of social difference may come to bear an inordinate weight; indeed, they may bear all the weight of the sufferings produced by capitalism in addition to that attributable to the explicitly politicized marking' (Brown, 1995: 60). Other identities have to bear the surplus-investment from the class struggle whose extent is not acknowledged. Capitalism is not just a phenomenon limited to the domain of economics but the structuring principle that over-determines the social totality. To place class as an equivalent identity, Zizek contends, is to depoliticise the economy.

Capitalist dynamics infuse and traverse all struggles (such as sexuality, race and gender) operating as the very background and terrain for their emergence of minority subjectivities. Class is not a category of identity but a perspective for approaching the continuous combat to configure life in the value-form against that which would resist it, and the forms of subjectivity that arises from class struggle (Zizek, 2000: 87). Class relations still determine life chances, health and wealth regardless of how people speak their relationship to them. Class relations are dynamic forces that underwrite all social encounters. Capitalism is the inequality generator shaping how people live, what they inherit and how they move through social space. To understand this process fully we need an analysis of an 'economy of personhood' within capitalism which can explain how different values - economic, cultural, symbolic, social, moral, can be accessed, attached and utilised and how they work through encounters that repeatedly enhance or diminish value in the person.

\section{NOTES}

1 We just need to turn to the literature of Jane Austen to see how this process between the upper and middle class is enacted through property relations and gender.

2 Yeo (1993) shows how middle-class women used working-class women to clean the dirty bits, enabling the middle class to appear as hygienic.

3 See Skeggs (2004) for an elaboration of this process.

4 See Yvette Taylor (2005) on how sexuality and class do and do not intersect. 
5 Although both race and gender identity politics have at different historical moments advocated antagonistic annihilation.

6 See (Butler, 1999)

7 Jacque Ranciere (1983) however, accuses Bourdieu of reproducing exactly that which he sets out to critique by 'measuring' homologies between class and taste and by quantifying the French education system in terms of class privilege.

8 This became highly apparent in a recent research project I conducted (for CRESC, Manchester University 2006) on the British government's 'Respect Agenda' (see http//:www.gov.org/respect). When a group of 10 ex-offenders now in higher education were given the agenda to discuss they melodramatically ripped it up, and put it in the bin, with shouts of 'respect, what respect, they've got no respect for us'.

9 The European Commission for Human Rights has been the major site for rights based claims

10 Some would identify this judgement as the narcissism of small difference for it is likely that the shop assistants could be sociologically identified as working class, but as Robbins observes, many servants in Victorian England took on the judgements of their employers against each other in order to generate a modicum of value for themselves. The significance of this move is that the judgement is repeated continually across a range of sites, so it is the recurring effect of the negative judgement, rather than the small difference that is significant.

11 During the writing of this chapter I went to have my hair cut. The hairdresser told me a joke about two Essex girls (the geographical euphemism for London working-class) at the perfume counter. What is it about perfume counters?

12 Referring to excessive Burberry clad, gold wearing, loud, white, working-class youth. Bogan (in Australia) and White Trash and/or Hillbilly are similar figures of fear and loathing. The women receive extreme vilification through association with reproduction: 'pram face' (personified in British 'alternative' comedy - The Catherine Tate Show)

13 See Rahjan Khanna (2007) for a brilliant discussion of the problems with the concept of dignity.

14 Qualities also identified by Eva Illouz (1997) in her research on class differences in attitudes to romance.

15 Although see Larry M. Bartels (2005) who challenges Frank's general argument with specific statistical analysis of voting habits, showing that it is the middle-class that have moved further right in moral voting issues. In the US the book is called 'What's wrong with Kansas'. In the UK, 'What's wrong with America'.

16 CRESC (Manchester) 2007 'Contingencies of Value'.

\section{REFERENCES}

Ahmed, S. (2004) 'Affective economies', Social Text, $22(2): 117-39$

Althusser, L. (1971) Lenin and Philosophy and Other Essays. London: New Left Books.

Altman, D. (2001) Global Sex. Chicago, IL: Chicago University Press.

Austin, J. (1962) How to Do Things With Words. Oxford: Clarendon.

Bartels, L.M. (2005) 'What's the Matter With What's the Matter With Kansas?'. Washington, DC: American Political Science Association.

Bourdieu, P. (1979) 'Symbolic power', Critique of Anthropology, 4: 77-85.

Bourdieu, P. (1984)[1979] Distinction: A Social Critique of the Judgement of Taste. London: Routledge and Kegan Paul.

Bourdieu, P. (1985) 'The social space and the genesis of groups', Theory and Society, 14: 723-44

Bourdieu, P. (1987) 'What makes a social class? On the theoretical and practical existence of groups', Berkeley Journal of Sociology, pp. 1-17.

Bourdieu, P. (1989) 'Social space and symbolic power', Sociological Theory, 7: 14-25.

Bourdieu, P. (1992) Language and Symbolic Power. Cambridge: Polity Press.

Brenner, J. and Ramas, M. (1984) 'Rethinking women's oppression', New Left Review, 144: 33-72.

Brown, W. (1995) States of Injury. Princeton, NJ: Princeton University Press.

Butler, J. (1993) Bodies That Matter: On the Discursive Limits of 'Sex'. London: Routledge.

Butler, J. (1999) 'Performativity's social magic', in R. Shusterman (ed.), Bourdieu: A Critical Reader, pp. 113-129. Oxford: Blackwell.

Callinicos, A. and Harman, C. (1987) The Changing Working-Class: Essays on Class Structure Today. London: Bookmarks.

Cannadine, D. (1988) Class in Britain. New Haven, CT: Yale University Press.

Charlesworth, S. (2000) A Phenomenology of Working Class Experience. Cambridge: Cambridge University Press.

Cohen, A.K. (1955) Delinquent Boys: The Culture of the Gang. Chicago, IL: Free Press.

Coulter, A. and Gurley, G. (2002) 'Coultergeist', New York Observer, Newssheet, pp. 27-29. New York.

Crompton, R. (1993) Class and Stratification: An Introduction to Current Debates. Cambridge: Polity. Crossick, G. (1991) 'From gentlemen to the residuum: Languages of social description', in Victorian Britain, 
in P. J. Corfield (ed.), Language, History and Class, pp. 150-178. Oxford: Blackwell.

Duncan, S. (2005) 'Mothering, class, rationality', Sociological Review, 53 (1): 50-76.

Duneier, M. (1992) Slim's Table: Race, Respectability and Masculinity. Chicago, IL: University of Chicago Press.

Eagleton, T. (1989) 'The ideology of the aesthetic', in P. Hernadi (ed.), The Rhetoric of Interpretation and the Interpretation of Rhetoric, pp. 79-87. Durham, NC: Duke University Press.

Engels, F. (1958[1844]) The Condition of the WorkingClass in England. St Albans: Panther.

Finch, L. (1993) The Classing Gaze: Sexuality, Class and Surveillance. New South Wales Sydney: Allen and Unwin.

Foucault, M. (1979) The History of Sexuality: Volume One, an Introduction. London: Penguin.

Frank, T. (2004) What's the Matter with America: The Resistable Rise of the American Right. London: Secker and Warburg.

Frazer, E. (1992) 'Talking about gender, race and class', in D. Cameron, E. Frazer, P. Harvey, M.B.H. Rampton and K. Richardson (eds), Researching Language: Issues on Power and Method, pp. 281-290. London: Routledge.

Goldthorpe, J. (1996) 'Class analysis and the reorientation of class theory: The case of persisting differentials in educational attainment', British Journal of Sociology, 45: 211-33.

Haylett, C. (2001) 'Illegitimate subjects? Abject whites, neoliberal modernisation and middle class multiculturalism', Environment and Planning D: Society and Space, 19: 351-70.

Hennessy, R. (2000) Profit and Pleasure: Sexual Identities in Late Capitalism. London and New York: Routledge.

Hoggart, R. (1957) The Uses of Literacy. London: Penguin.

hooks, b. (2000) Where We Stand: Class Matters. London: Routledge.

Illouz, E. (1997) Consuming the Romantic Utopia: Love and the Cultural Contradictions of Capitalism. Berkeley, CA: University of California Press.

Kelly, P. (2007) 'Filipino Migration, Transnationalism and Class Identity' WPS 90. Singapore: Asia Research Institute, National University Singapore.

Khanna, R. (2007) 'Indignity', Ethnic and Racial Studies, 30 (2): 257-81.

Kirk, J. (2007) Class, Culture and Social Change: On the Trail of the Working-Class. Basingstoke: Palgrave Macmillan.
Kuhn, A. (1995) Family Secrets: Acts of Memory and Imagination. London: Verso.

Lamont, M. (2000) The Dignity of Working Men: Morality and the Boundaries of Gender, Race and Class. Cambridge, MA: Harvard University Press.

Lawler, S. (2000) Mothering the Self: Mothers, Daughters, Subjects. London: Routledge.

Lawler, S. (2002) 'Mobs and monsters: Independent man meets Paulsgrove woman', Feminist Theory, 3 (1): 103-13.

Macpherson, C.B. (1962) The Political Theory of Possessive Individualism. Oxford: Oxford University Press.

Marx, K. and Engels, F. (1968[1848]) Manifesto of the Communist Party. London: Lawrence and Wishart.

Matza, D. (1964) Delinquency and Drift. New York: Wiley.

McClintock, A. (1995) Imperial Leather: Race, Gender and Sexuality in the Colonial Context. London: Routledge.

Miller, W.B. (1958) 'Lower class culture as a generating milieu of gang delinquency', Journal of Social Issues, 15: 5-19.

Mount, F. (2004) Mind the Gap: Class in Britain Now. London: Short Books.

Nead, L. (1988) Myths of Sexuality: Representations of Women in Victorian Britain. Oxford: Blackwell.

Ortner, S. (1991) 'Reading America: Preliminary notes on class and culture', in G.R. Fox (ed.), Recapturing Anthropology: Working in the Present, pp. 163-191. Santa Fe, NM: School of American Research Press.

Ranciere, J. (1983) The Philosopher and His Poor. Durham, NC: Duke University Press.

Reay, D. (1998) Class Work: Mother's Involvement in their Children's Primary Schooling. London: UCL Press.

Ruddick, S. (2006) 'Abnormal, the 'new normal' and destabilizing discourses of rights', Public Culture, 18 (1): 53-77.

Savage, M. (2000) Class Analysis and Social Transformation. Buckingham: Open University Press.

Savage, M. (2003) 'A new class paradigm? Review article', British Journal of Sociology of Education, 24 (4): 535-41.

Sayer, A. (2005) The Moral Significance of Class. Cambridge: Cambridge University Press.

Sennett, R. and Cobb, J. (1977) The Hidden Injuries of Class. Cambridge: Cambridge University Press.

Skeggs, B. (1997) Formations of Class and Gender: Becoming Respectable. London: Sage.

Skeggs, B. (2004) Class, Self, Culture. London: Routledge. 
Spinoza, B., de (1996) Ethics. London: Penguin.

Stanworth, M. (1984) 'Women and class analysis: A reply to Goldthorpe', Sociology, 18 (2): 153-71.

Ste. Croix, G., de. (1981) The Class Struggle in the Ancient Greek World. London: Duckworth.

Steedman, C. (1999) 'State sponsored autobiography', in B. Conekin, F. Mort and C. Waters (eds), Movements of Modernity: Reconstructing Britain 1945-1964, pp. 103-122. London: Rivers Oram.

Steedman, C. (2000) 'Enforced narratives: Stories of another self', in T. Cosslett, C. Lury and P. Summerfield (eds), Feminism and Autobiography: Texts, Theories, Methods, pp. 25-40. London: Routledge.

Strathern, M. (1992) After Nature: English Kinship in the Late Twentieth Century. Cambridge: Cambridge University Press.

Thompson, E.P. (1966) The Making of the English Working Class. Harmondsworth: Penguin.

Thompson, J. (1996) Models of Value: Eighteenth Century Political Economy and the Novel. Durham, NC: Duke University Press.

Vicinus, M. (1974) The Industrial Muse: A Study of Nineteenth Century British Working Class Literature. London: Croom Helm.

Wahrman, D. (1995) Imagining the Middle-Class: The Political Representation of Class in Britain, c. 1780-1840. Cambridge: Cambridge University Press.
Walkerdine, V. and Lucey, H. (1989) Democracy in the Kitchen: Regulating Mothers and Socialising Daughters. London: Virago.

Walkerdine, V., Lucey, H. and Melody, J. (2001) Growing up Girl: Psychosocial Explorations of Gender and Class. Basingstoke: Palgrave.

Ware, V. (1992) Beyond the Pale: White Women, Racism and History. London: Verso.

Weis, L. (2004) Class Reunion: The Remaking of the American White Working Class. New York: Routledge.

Williams, R. (1988) Keywords: A Vocabulary of Culture and Society. London: Fontana.

Willis, P. (1977) Learning to Labour: How Working Class Kids Get Working Class Jobs. Farnborough: Saxon House.

Wright, E. (1985) Classes. London: Verso.

Yeo, E. (1993) The Contest of Social Science in Britain: Relations and Representations of Gender and Class. Lancaster: Lancaster University.

Zizek, S. (1997) 'Multiculturalism, or, the cultural logic of multinational capitalism', New Left Review, 225: $28-52$

Zizek, S.(2000) 'Class struggle or postmodernism: Yes, please!', in J. Butler, E. Laclau and S. Zizek (eds), Contingency, Hegemony, Universality: Contemporary Dialogues on the Left, pp. 90-136. London: Verso.

Zizek, S. (2004) 'Over the rainbow', London Review of Books, 4 (11): 20. 